\title{
Gagging Electoral Fraud in Nigeria: The Imperative of Electoral Reforms
}

\author{
Christiantus Ifeanyi Adebowale Oke ${ }^{*}$, Harriet Omokiniovo Efanodor-Obeten ${ }^{2}$ \\ 1,2Dept. of Political Science \& Public Administration Edo University Iyamho, Edo State, Nigeria* \\ ${ }^{*}$ Corresponding Author Email:chris.oke@edouniversity.edu.ng
}

\begin{abstract}
Elections all over the world are the only recognized legitimate means of changing and constituting governments. In other democratic climes, citizens eagerly await elections with excitement, because it affords them the opportunity to appraise the scorecards of their elected representatives. However, preparing for elections in Nigeria is akin to getting set for a major warfare that requires humongous human and natural resources including the deployment of full military arsenal. Despite the unease this vital democratic practice puts the nation, elections are fraught with irregularities and malfeasances. The crux of this paper is to adumbrate what constitutes electoral fraud and proffer possible panaceas using the instruments of electoral reforms. The study utilizes secondary source of data and content analysis as its methodology and use qualitative approach. The paper argue s that electoral malpractices manifest in diverse forms and are orchestrated by the political class to perpetuate themselves in office. It is also the opinion of this study that if there is a holistic electoral reform, most politicians that are currently occupying offices might not get valid chance of winning (re)elections, hence, their stiff opposition and resistance to the reforms. This paper recommend samongst others that the 9 th National Assembly should as a matter of urgent national importance, timely debate, update and represent the Electoral (Amendment) Bill to the President for his assent. Furth ermore, it is recommend ed that for free, fair and credible elections to take place, technology should be embraced and Electoral Offences Commission should be established to prosecute electoral fraudsters.
\end{abstract}

Keywords: Democratic System, Electoral Fraud, Electoral Reform, Electoral Process, Electronic Voting

\begin{abstract}
Abstrak
Pemilu di seluruh dunia adalah satu-satunya cara sah yang diakui untuk mengubah dan membentuk pemerintahan. Dalam iklim demokrasi lainnya, warga dengan antusias menunggu pemilihan dengan gembira, karena hal itu memberi mereka kesempatan untuk menilai kartu skor dari perwakilan terpilih mereka. Namun, mempersiapkan pemilu di Nigeria mirip dengan bersiap untuk perang besar yang membutuhkan sumber daya manusia dan alam yang sangat besar termasuk pengerahan persenjataan militer penuh. Terlepas dari ketidaknyamanan yang ditimbulkan oleh praktik demokrasi yang vital ini, pemilihan umum penuh dengan penyimpangan dan penyimpangan. Inti dari artikel ini adalah untuk memahami apa yang merupakan kecurangan pemilu dan menawarkan obat mujarab yang mungkin menggunakan instrumen reformasi elektoral. Penelitian ini menggunakan sumber data sekunder dan analisis isi sebagai metodologi serta menggunakan pendekatan kualitatif. Makalah ini berpendapat bahwa malpraktek pemilu terwujud dalam berbagai bentuk dan diatur oleh kelas politik untuk melanggengkan diri mereka sendiri di kantor. Studi ini juga berpendapat bahwa jika ada reformasi elektoral holistik, sebagian besar politisi yang saat ini menduduki jabatan mungkin tidak mendapatkan kesempatan yang valid untuk memenangkan (kembali) pemilu, karenanya, mereka menjadi oposisi dan perlawanan yang kuat terhadap reformasi. Makalah ini merekomendasikan antara lain bahwa Majelis Nasional ke-9 harus sebagai masalah kepentingan nasional yang mendesak, debat tepat waktu, memperbarui dan mewakili RUU Pemilu (Amandemen) kepada Presiden untuk persetujuannya. Selain itu, disarankan agar pe milu yang bebas, adil, dan kredibel berlangsung, teknologi harus diterapkan dan Komisi Pelanggaran Pemilihan harus dibentuk untuk menuntut para penipu pemilu.
\end{abstract}

Kata kunci: Sistem Demokrasi, Penipuan Pemilu, Reformasi Electoral, Proses Pemilihan, Pemungutan Suara Elektronik

\section{* Copyright (c) 2021 Christiantus Ifeanyi Adebowale Oke and Harriet Omokiniovo Efanodor- Obeten}

This work is licensed under a Creative Commons Attribution-ShareAlike 4.0 International License. 


\section{INTRODUCTION}

One of the cardinal features of the democratic process is elections, which can be described as a modern and widelyagreed means by which individual sare freely and methodically chosen to representa body or society in a larger institution or government by voting. (Belloumar \& Lamidi, 2018). Elections in Nigeria, on the other hand, have been a political liability, a source of uncertainty and degradation, rather than a political advantage and legitimizing power, sinceindependence. Contrary to expectations, elections have become a night-mare in Nigeria (Confidence Chia \& David Nchinda, 2018). Nigeria's numerous encounters with competitive democratic politics have resulted in the worst forms of political thuggery and brigandage, as well as unmediated and unrestrained crime..

In the light of the above, election and electoral process in Nigeria have been the bane of our democratic consolidation (Ojukwu et al., 2019). In the history of electoral politics in Nigeria, the vital connection between elected and electors necessary for a liberal democracy has been missing. Furthermore, thephenomena of electoral fraud during election have been the bane of successive elections in Nigeria (Fatai, 2018). This has rendered the whole process inequitable, undemocratic and dangerous. The result is that the government emerging from such elections suffers crisis of legitimacy.

From 1922 till date in Nigeria's electoral history, there are clear evidences to demonstrate the fact that Nigerian elections are characterized by fraud. Commenting on the level of malpractices in the 1965 elections. Ebong \& Ozinegbe (2020) observed that the controversial elections of 1965 were largely responsible for the coup de tat of January 1966. Elections in Nigeria have also been likened by several Nigerian scholars to warfare (Adekanye, 1988; Mawere \& Mwanaka, 2015). Some scholars have argued that, in Nigeria, the fear of election is the beginning of political wisdom (Gberevbie, 2014). To this extent, it is often the case at the highest point of election times that Nigerians look to it with trepidation (Nwachukwu, 2018).

The above, prompted Adekanye (1988) to counsel that election periods in Nigeria should be declared as state of emergency. This is because the electoral process has been rendered vulnerable to abuse and ambushed by massive rigging and other forms of electoral fraud by partiesin power or others seeking to manipulate institutional levers in their own interest to win power. The outcomes of elections are often neither the reflection of the true choice of the electorate nor are they accepted.

As such, political heresy demonstrates the gravity of th eproblems associated with electoral politics and the dangers they pose to the consolidation of democracy in Nigeria (Ashindorbe, 2018; Joseph, 2020; Osha, 2020).The fact that the most recent 2015 election series and the 2019 elections also contributed to a dose of electoral warfare is a clue to the fact that Nigeria's nascent democracy is in jeopardy. Thus, the main rationale for electoral reforms in Nigeria is rooted in the historiography of Nigerian elections. However, research related to this matter is still lacking. This study sheds light on what constitutes electoral fraud and offers a possible panacea by using electoral reform instruments. For the time being we argue that if there is a holistic electoral reform, most of the politicians currently in office may not get a valid chance to win (return) the election, therefore, they are in opposition and fierce resistance to reform.

\section{RESEARCHMETHOD}

This study describes the democratic process in Nigeria with an electoral system that is held for electoral elections, we begin our research by determiningthe theoretical basis of the meaning of election fraud and democratic reform, which will lead us to conclusions as a basis for refining this research. Next, we identify the fraud that occurred during the elections in Nigeria and discuss the findings as an alternative 
answer to the problem, namely democratic reform. To support this research we use a qualitative approach from Urquhart (2012) with data sources in the form of government documents, relevant research results and direct observations. After the data is obtained to get a further view, we perform an analysis using content analysis theory from Schreier et al (2020).

\section{RESULTS AND DISCUSSION}

\section{Result}

\section{Electoral fraud and Electoral Reform in Nigeria: Conceptual and Theoretical Underpinning}

Ekiugbo and Umukoro (2011) describe electoral fraud as an illegal interference with the process of an election. However, Ekiugbo and Umukoro (2011) limit the acts of fraud to those thattend to involve affecting vote counts to bring about a desired election outcome, whether by increasing the vote share of the favoured candidates, depressing the vote share of the rival candidates, or both. In contrast, Oni (2004) posits that a meaningful discussion of electoral fraud in Nigeria must touch all activities related to electoral process as identified by Kurfi cited in Onias (i) establishing and equipping pollingstationsand booths (ii) recruitment, training and development of electoral officials, (iii) provision of logistics and electoral officers (iv) publicity and public enlightenment (v) fixing the dates of elections (vi) registration and screening of nominations. (vii) Directing voters on how to cast their votes each time an election takes place. (Viii) Counting of votesand declaration of results (ix) provision of security at the pooling booths.

Egwemi in Ndubuisi \& Ebubechukwu (2021) agrees with the above thatelectoral fraud should not be limited to the conduct of elections alone. For him, all electoral processes or stages are open to fraud. Thus, he conceptualized electoral fraud as those activities/manip ulations capable of distorting facts and not restricted only to the voting day. He further stated that electoral fraud denies the fundamentals/ tenants of the electoral process/democracy as the expressions of the popular wish of the people. Ekiugbo and Umukoro (2011) The first suspicion of electoral fraud in the Athenian democracy was reported in 471 BC, according to historians. Archaeologists discovered 190 pieces of broken pottery that were used as ballots at the time, with just 14 distinct handwriting. As a result, they came to the conclusion that election fraud is likelyas old as elections themselves..

Egwemi in Ndubuisi \& Ebubechukwu (2021) citing Tella proposed two classifications of electoral fraud as (a) pre-election manipulations and (b) post-election manipulation. Heidentified the following as pre-election manipulation; tailoring electoral laws to disenfranchise candidates or groups of individuals, technical disqualifications of candidates by attempting to arm-twist the electoral body with strict rules; cultic candidate selection process to sideline some people; ethno-cultural and religious manipulations of the election process; monetization of the electoral procedure before selection of candidates at party and electoral commission level and ballot stealing. The post-election manipulations are; deliberate refusal to count ballot boxes from opposition strongholds; doctoring of results between the voting centers and collation centers; outright theft of ball ot boxes after voting and outright cancellation of election result.

Ekiugbo and Umukoro (2011) in their study focused on electoral fraud techniques such as; voter intimidation and coercion; physical tempering that involves ballot stuffing and theft or destruction of ballot boxes and materials; inflation or deflation of voters list; social engine ering such as election officials misinforming voters; impersonation of voter; manipulation during tabulation in the polling place; 
manipulation during central tabulation of the result and manipulation through legislative means such as creating election deadlinesthat are unreasonable to certain portions of the electorate.

Oni's (2004) classification of forms of electoral fraud dwelled on various forms of election manipulation that occur during the actual voting exercise. These manipulations according to him, take different forms such as; stuffing of ballot boxes with legal or illegal ballot papers; starving of opposition strongholds with electoral materials with a view to disenfranchising them their right to choose. Multiple voting; voting by non-registered members; underage voting; misdirecting of the illiterate or ignorant voters to vote against their choice, amongst others. Ekiugbo and Umukoro (2011) are of the view that Electoral fraud is not limited to political polls; it can occur in any election where the possible advantage outweighs the risk, such as elections for trade union leaders, student councils, sports judging, and awards for books, films, music, or television programming. In this paper, we conceptualized electoral fraud as an illegal interference and manipulations with the processes of pre-election, voting day and post elections.

On the other hand, to conceptualize electoral reform is to ask a simple question: what is electoral reform within the Nigerian context? It simply means to make proposals and amendments to the electoral legal framework that will guarantee that votes cast by the electorate will count and that the electioneering process will inspire confidence amongst the citizens, observers, development partners and the international community. To implement these proposals and amendments, a paradigm shift in thinking about electoral reform is needed, as is facilitating consensus among key political actors and relying on a consultative process to aggregate society's needs and preferences. Electoral reform in Nigeria would mean answering the never-ending issue of security agencies' neutrality during elections, as shown by previous elections in which security forces were used for personal gain against the will of the people. Politiciansare still one step ahead of the electoral commission in undermining the electoral process, according to various election fora. Furthermore, with police officersup for grabs, manipulating security apparatuses becomes much easier. According to Isah (2020), A thoroughly revised electoral act will resolve key concerns that will help to improve Nigeria's elections. The creation of an electoral offense body, for example, would ensure that electoral criminals are punished appropriately. Although INEC is r esponsible for prosecuting criminals, it lacks the technological capacity to carry out this crucial aspect of elections.

The dynamics of electoral fraud and electoral reform in Nigeria's electoral processes can be best explained and understood under a specific theoretical underpinning. This is because the underlying theoretical underpinning for the explanation of the process of elections has an overlapping effect in bringing to the fore the various forms of electoral malpractice. Accordingly, the study adopts the group theory as a base for this analysis. Advocates of the group theory argue that every culture contains a large number of people who are constantly fighting for control and dominance over oneanother. These groups are involved in a process of balancing and restricting one another, in order to preserve unity between the different interests in society, of which these groups were the proponents. The utility of the group theory derivesits origin from the work of Bentley (2013) and David Truman (1951).

Within the context of the positive evaluation of the group theory, the group theory framework provides the theoretical platform for useful contemporary political analysis of the electoral fraud in Nigeria and its implication on electoral reforms. Using the pluralist model of group theory, electoral fraud in present day Nigeria could not be divorced from the influence and role of groups, who rely on electoral rigging or fraud to pursue and achieve their own political and economic interest and benefit. Political parties as a group in Nigeria are operated by political godfathers who usem oney and violenc eto control the political process. They decide party nominations and campaigns outcome and they also have a means of determining the outcomes of elections. Many political parties especially parties of the incumbents, rely 
on electoral fraud rather than popularity to stay in power. And in return while in power opposes holistic electoral reforms aimed at tinkering the electoral system. This is because these groups (political parties/ politicians) that are occupying offices might not get valid chance of winning (re)elections, hence, their stiff opposition and resistance to the reforms. Thus, the above analysis explains the relevance of the group theory to understanding the gagging of electoral fraud in Nigeria. The next section in specific term highlights the various mode of electoral fraudsin Nigeria.

\section{Detecting the Modes of Electoral Frauds in Nigeria}

Elections in Nigeria have always generated heated controversies. There is hardly any type of election that does not end at election petition tribunals, courts of appeal and in some cases, the Supreme Court. One thing is constant: election results are always disputed. There are accusations and counter accusations of diverse riggings and electoral frauds by candidates and their political parties alike. Electoral malpractices are as old as Nigeria. Beginning from the 1959 General Elections through the various postindependence regional elections to the modern era, Nigeria has never got it right when it comes to selecting or electing representatives at various levels, as politicians often engage in a rat-race to secure numerical strength at elections albeit using manipulative tendencies. For example, in a post mortem examination of the 1979Presidential Election, Adamu and Ogunsanwo (1982), reviewed the 1979 Voters' Register and submitted a graphic picture of attempts to achievequestionable majority rule by ambitious politicians byintently manipulating the voters' registration exercise.

Aluaigba (2016), contend that it is against these desperate moves and sharp practices toward elections or at elections by politicians to achieve majority rule by hook and crook that differentattempts have been made by electoral management bodies (EMBs) to frustrate these desperations. To that end, different systems of voting have been experimented. In the 1991 and 1993 elections, Nigeria opted for Open Ballot System and Modified Open Ballot System respectively, to conduct elections. Consequently, Ujo (2012), maintained that the two innovations had their inherent challenges. In the first place, the methods did not guarantee the much needed secrecy and confidentiality of choice. Again, the systems gave rise to victimization and harassment of electorate or community byeither the winning or losing party. Asa result, the voting systemswere soon to be jettisoned.

At this juncture, it is pertinent to articulate therangeand dimensions of electoral frauds in Nigeria with a view to proffering solutions. It is important to state that these electoral misdemeanors appear in divergent form sand phases. To thisend, Avgerou (2019) constructed a typology of electoral malpractice based on two main categorizations viz: material dimension and psychological dimension. While material manipulation involves direct tempering with the physical aspects of elections such as voters' list, ballot papers, communication or computer equipment, vote-buying, operational impediments that deprive minorities (people with disabilities, the poor, women and youth from exercising their franchise, even the control of electoral agencies to facilitate electoral victory. The psychological aspect of electoral fraud include tampering in the form of offer of employment or threat of termination of same, payment of commissions on services rendered, commitments or promises of future juicy government contracts, provision of petty cash or foods to electoral officers on election duty, violence against opposition, heavy and unreasonable deployment of security agencies which purpose is to intimidate voters and instill fears, etc.

On the other hand, Birch (2011), has a typology based on four categories of electoral manipulations. They are:

1. Manipulation of institutions; 
2. Manipulation of the voting act;

3. Manipulation of voter choice; and,

4. Manipulation of the outcome.

Manipulation of institutions is usually perpetrated by the electoral management bodies (EMBs) or by the government in power. It can manifest in diverse ways including structuring the elections to the advantage or disadvantage of any of the contestants in clear or subtle violation of the principles of inclusivity, impartiality, openness or transparency. For instance, this could involve illegal voter registration, alteration of voter-registration lists, over-restrictive franchise.

Again, manipulation of the voting act has to do with the uneven implementation of the regulatory framework; biasing of administrative decisions in favour of one of the contestants; stoppage of voting in one or more polling areas while allowing the process to go on in some other polling stations at the same time; outright stuffing of the ballot box; misleading and confusing ballot papers; absence or shortage of election materials. Others include expulsion of political parties' agents from the polling stations thereby, preventing them from monitoring the voting exercise; permitting double or multiple voting by individuals with plenty voters' cards; forcing voters to vote for a particular candidate or political party, etc.

Birch (2011), manipulation of voter choice includes all the kinds of undue influence for voters to misrepresent their true preferences such as vote-buying and clientelistic transactions, or negative sanctions such as violence and intimidation. In Nigeria, violence and intimidation in the electoral process take the forms of kidnapping, murder of candidates and their supporters, preventingvotersfrom reaching the polling stations, attacks on polling stations in areas that are known or perceived to support a certain candidate or party.

The fourth category of electoral fraud accordingto Birch isthe manipulation of election outcome or result. And this can manifest in various dimensions including wrongvote counting, mis-recording of votes, inflation of votes, switching of scores, deliberate destruction or invalidation of b allots, disappearance of ballot boxes from the opponents' mainstay, preventing voters from watching and observing vote counting. Other forms include locating polling stations in private residences of party stal warts, counting ballots in the darkwith the intention to stuff the ballot boxes, replace genuine boxes with pre-thumb-printed ballots, manipulate counting, partially cancelling electionsto give advantage to a party or candidate.

The overall implications and effects of electoral malpractice are multifaceted. In the first instance, any candidate or government that emerges in suspicious circumstances is easily confronted with credibility and legitimacy crisis. Constituents or the populace do not trustsuch occupiers of governmental offices. In this situation, commanding loyalty and eliciting popular support become a herculean task for the regime.

Furthermore, when the electorate know that their votes will not count, it has a tendency to erode confidence in the electoral process. This is very dangerous for democracy and mass mobilization of the citizenry for participation in the running of the affairs of the State. In addition, according to Mauk (2020), while various electoral malfeasancesare witnessed in varying degrees in all democratic societies, they are more rampant in democratizing societies like those in Africa. In Sub-Saharan Africa, there are not a few conflicts that have been caused by electoral frauds and miscarriage of electoral justice. In Nigeria, there have been several crises that were orchestrated by electoral malpractice leading to humongous loss of lives and property. That explains why the current efforts and search for solution to halt the trend of election fraud is not only timely but worthwhile. 


\section{Discussion}

\section{Electoral Reforms: its Imperatives in Nigeria's Democratic stability}

Since the end of the Cold War, periodic elections have become almost universal. However, independence and democracy are on the decline in many countries where elections are held. They are intended to be toolsfor peacefulgovernment reform, butthey also become flashpointsfor political conflict. Electionswithout honesty are at the heart of these contradictions. Frequently, Elections merely provide a veneer of legitimacy to despotic regimes. Elections without dignity, on the other hand, cannot provide legitimacy to the winners, protection to the losers, and public trust in their leaders and institutions. This leaves polities vulnerable because it allows dissatisfied groups to seek out ther, less productive means of expressing their dissatisfaction. After more than twenty years of return to civil rule, Nigeria has been grappling with the challenges of getting elections right and minimizing huge petitions that follow each round of elections and the consequent viciousness and costsassociated with such elections.

Elections are increasingly becoming marred by violence and intimidation, with the role of the security agencies becoming more contentious. This situation is likely to damage the integrity of any electoral process and may deter future participation. As a result, Nigerians and the international community have renewed their call for a genuine, holistic and all-encompassing electoral reform. What are the benefits of electoral reform in Nigeria's search for a more credible electoral process?

The key justification for electoral reform in Nigeria is rooted in the history of Nigerian elections, which has been described as a history of competitive rigging by some (Oloruntoba et al., 2020). For the better part of the country's political evolution (pre- and post-independence) Electoral problems have been one of the most powerful influences on the State's election cycle. Elections in Nigeria have lost their democratic substance and significance over time, owing to a failure to honor the social contract between the governed and the government that elections are supposed to represent $(\mathrm{Kew}, 2010)$. Despite the fact that under colonial rule and in the immediate post-independence period, electoral politics was rooted in ethnicity, elections were still able to guarantee some level of quality and the social contract. This was expressed, for example, in thepresence of a vibrantand "ethnicized" opposition and coalition politics, both of which are essential for the health of democracy.

According to Omotola (2011), this began to change during the Second Republic and the situation has worsened since theannulment of the 12 June 1993 presidential election. The reasonsfor the country's electoral frauds are the colonial foundation of the state, coupled with the neo-patrimonial nature of its post-independence variant, which have served to undermine the development of the institutional and systemic architecture for effective electoral governance. These problems reached a climaxin the aftermath of the 2007 'garrisoned' election. But how can the ugly tide of electoral mal practicesbetamed? There have been several efforts and attempts made toward clipping the wings of electoral malfeasances in the past. But politicians have always found a way to beat the laws, policies and measuresin other to achieve their selfish ends. Even the 2010 Electoral Act was ferociously breached and abused in many fronts before, during and after the 2015 General Elections.

The flagrant violations of the Electoral Act's campaign spending cap are one example of such abuses. On December 21,2014, for example, 21 governors of the Peoples Democratic Party (PDP) donated millions of Naira.Before the 2015 elections, the 21 governors contributed a total of $\mathrm{N} 1.05$ billion to their political party. The governors' donation was part of the $\mathrm{N} 21.2$ billion raised by the party at the fund raising dinner held at the Presidential Villa, Abuja (Observasion Premium Times, 21 December, 2014). 
The N21.2 billion raised was in excess of the N1 billionlimit set by the Electoral Act. Despite the fact that there were significant contributions from private donors as well as other organisations, the donors remained anonymous. This was in violation of the 2010 Electoral Act's requirement that all sources of campaign funding be revealed. Furthermore, the two major political parties violated the Electoral Act by exceeding expenditure limits, as stated in the following parts of the Electoral Act 2010 (as amended): The Act's section 91(2) readsas follows:, "an individual or other entity shall not donate more than N1 Million to any candidate". Sub-section 10 of the same section adds that a presidential candidate "who knowingly acts in contravention of this section commits an offence and on conviction is liable to a maximum fine of N1 Million or imprisonment for a term of 12 months or both" in Electoral Act 2010.

The above contributions were also in violation of Section 221 of the 1999 constitution, which forbids a state government from contributing to any candidate or aspirant's election expenses. Furthermore, the governing laws have been tampered with byboth the PDP and the APC. For example, the PDP spent N3.55 billion on publicity between December 2014 and February 2015, while the APC spent N1.42 billion (Onuba, 2015). This does not include their expenditures after the election's postponement from February 28, 2015 to March 28, 2015. In turn, the political parties' actions and the numerous donations made were in violation of the $\mathrm{N} 1$ million cap on individual campaign contributions.

Non-compliance with campaign time-frame lawsis another example of electoral act breaches. Both the ruling Peoples' Democratic Party (PDP) and the largestopposition, the All Progressive Congress (APC), broke campaign law (APC). They participated in election campaigns before political partieswere allowed to do so under the Electoral Act. The Transformation Ambassadors of Nigeria (TAN) coordinated one of these campaigns on a regular basis, with the primary goal of rallying support for President Goodluck Jonathan and Namadi Sambo's re-election bid in 2015. TAN staged numerous campaigns dubbed "Unity Rallies" in each of the country's six geopolitical zones. "The time of public campaigning by any political party shall start 90 days before polling day and end 24 hours prior to that day," according to Section 99 (13) of the Act. TAN's actionsalso violate Section 221 of the Federal Republic of Nigeria's 1999 Constitution. The Constitution clearly states that "no association, other than a political party, shall canvass for votes for any candidate atany election or contribute to the funds of any political party or to the election expenses of any candidate at an election".

Again, Following the police's failure to provide sufficient protection during political rallies by the two dominant political parties (PDP/APC) during electioneering campaigns in some states of the federation, it was an abuse of the Electoral Act. During rallies and processions in Katsina, Adamawa, Taraba, Kaduna, and Bauchi, irate youths stoned the PDP presidential candidate, President Goodluck Jonathan's convoy. There have been reports of armed thugs disrupting campaigns in Rivers State. For example, the APC campaign in Okrika was disrupted by attacks that resulted in the death of a police officer, Ifeanyi Okorie. during the rally (Akasike, 2016). As a result, the police's failure to protect electioneering campaignsin these states is a direct breach of Section 94 (1) of the Electoral Act, which states that "for the purpose of peaceful conduct of political rallies and processions, the Commissioner of Police in each state of the Federation and the Federal Capital Territory shall provide adequate security for processions at political rallies in thestates and the Federal Capital Territory,Abuja".

From the foregoing, one caninfer that the Justice Muhammed Uwais Commission that set the tone for the 2010 Electoral Act actually aimed at reforming the electoral system. The question is: why did it become necessary for the $8^{\text {th }}$ Nigeria National Assembly to thinker another reform? To answer the above poser, after the 2015 General Elections, it became obvious that there were a lot of loopholes and lacunas to be plugged if the perennial complaints of electoral frauds were to be mitigated. Prior to and during the 
extant elections, it became glaring that the provisions of 2010 Electoral Act were either insufficient to deter electoral malpractices or lacked enough poise to punish violators. Therefore, this paper firmly believes that among others, the under-listed areas need urgent attention for Nigeria to attain some level of credence and restore confidence in her subsequent elections.

Electronic Voting: Since then, one of the favored reforms has seen the use of technology in parts of the country's election process, especially with the implementation of card readers in 2015. However, the National Assembly passed sections 9 (1A\& 5), 15, and 49(1), (2) of the Electoral (Amendment) Bill 2018, which pursued deeper changes, inclu ding electronic voting and results transmission, as is the case in other democratizing societies such as Kenya. This means that the whole process of enrollment, accreditation, vote counting, collation, and announcement will be done electronically. The Electoral (Amendment) Bill 2018aimed to implement a number of amendments, including the implementation of electronicvoting and the use of technology in elections.

Electoral Offences Commission: As part of the electoral reform, there is need for the National Assembly to quickly complete all legislative work on this bill and urgently pass it into law. Special courts or tribunals are needed to speedily try electoral offenders. It has become manifest that theregular courts in Nigeria are encumbered with other civil and criminal cases that adding electoral matters to them for adjudication makes the wheels of quick dispensation of justice to grind even slower. Although there are Election Petition Tribunals but they are established solely to validate or invalidate an election on the grounds of compliance or non-compliance with provisions of the Act. Hitherto, neither the tribunals nor the Independent National Electoral Commission (INEC) has the power to arrest, investigate and prosecute electoral fraudsters.

Electoral Justice: It is a herculean task to demand for electoral reform without laying the foundations for electoral justice. It appears that the political class has decided to use the judiciary to consolidate their acts. There seems to be an indication that the political class has infiltrated the judiciary to the extent that there are incidences of double and contradictory judicial pronouncements on the same matter. This paper argues that the present state of the country's electoral laws allows election petitioners to be even more frustrated in their search for justice. As things stand, many judicial authorities have added to petitioners' frustrations, with several rulings holding that an election cannot be challenged on the basis of corrupt practices. Despite the fact that many votes were marred by fraud, judicial authorities upheld them. For example, a complainant must show that there is significant non-compliance and that the noncompliance has had a significant impact on the election results. In Yussuf v Obasanjo, the cou rtruled that an election cannot be called into doubt because of alleged corruption. It was held in Falaev Obasanjo that it must be shown that a financial inducement was approved by the election winner. In Buhariv Obasanjo, it was decided that the applicant bears the burden of proving electoral malpractice. The theory of substantial enforcement has been used to uphold many fraudulent elections. Winners of rigged elections were allowed to participate in rerun elections mandated by the courts in a number of cases(Ojo, 2019).

Cost of Handling Election Petitions: There is no doubt that no election will be perfect or free from disputes and contestations. However, the electoral system must necessarily create the enabling environment and ambiance that guarantee level playinggr ound and at the same time, afford those that disagree with the outcome of the election the opportunity to explore legal avenues to ventilate their grievancesand seek redress. This legal option should be affordable and within the reach of any aggrieved political actor that wishes to take advantage of it. This is because the process of dealing with complaints and resolving election disputes is critical to the survival of any democracy, particularly a fragile one like Nigeria.If the cost of filing and procuring relevant documents at election petitions tribunals is way beyond 
the reach of candidates of less popular political parties, who are largely self-funding, who also might not muster enough financial muscles to deploy the massive array of evidence and witnesses required to upturn the apple cart, it is capable of dissuading potential petitioners from challenging the outcome. Although the 1999 Constitution stipulates that election petitions must be disposed of within 180 days of filing, "access to relevant election materials or documents by candidates in the election for purposes of election petition continued to be a challenge with the Independent National Electoral Commission levying very exorbitant fees for issuance of certified true copies of the election results and other election documents to candidates" (Ojo,2019).

Reduction in the Cost of Politics: it glaring that elections and electioneering campaigns are too expensive. To run for any position in Nigeria, aspirants need to set aside tons of money to remain visible. This is likely to scare away potential contestants who do not have enough financial war-chest. When politics and elections are highly monetized, those worst hit are usually women and the youth. If women and the youth are unwittingly schemed out of the race by any design, the political system suffers from gaining from those critical groups of the society. Section 91(2) of the Electoral Act, 2010, places a maximum limit on election expenses that can be incurred bycandidates as follows:

1. Presidential election- $\mathrm{N} 1,000,000,000$ (One Billion Naira),

2. Governorship election- N200,000,000 (Two Hundred Million Naira),

3. Senatorial seat in at an election to National Assembly- N40,000,000 (Forty Million Naira),

N20,000,000 (Twenty Million Naira) for the Federal House of Representatives, and so on. Any individual or organization that donates more than N1,000,000 (One Million Naira) to a nominee is in violation of Section 91(9). Candidates who surpass the amounts specified are subject to penalties under Section 91(10). Now, it is obvious that this section of the Act is no more in tandem with modern realities and; consequently, should be reviewed with a view to bringing Nigeria's electorallaw up to speed.

\section{CONCLUSION}

In Nigerian politics, the sad reality about electoral politics in the nation's attempt at democratic consolidation is that each of the identified activities involved in the electoral process is prone to manipulation. Electoral processes, therefore, in this regard cannot guarantee a legitimized democracy capable of eliciting necessary support, acceptability and cooperation that are essential to move the nation forward. The foregoing has reignited calls for real, comprehensive, and all-encompassing electoral reform. Also, having an election process that is fully open to all voters, from candidate selection to vote casting and tabulation, is the best way to protect the electorate from electoral fraud. An electoral amendment at this point will not only restore citizens' faith in the electoral process, butwill also help to alleviate political party bottlenecks, especially in terms of nomination form costs. The most significant playersin the process, apart from politicians, are the people, whose votes are supposed to determine the election winner.

\section{REFERENCES}

Adamu, H. al-R., \& Ogunsanwo, A. (1982). Nigeria: The Making of the Presidential System: 1979 General Elections. Triumph Publishing Company Limited.

Adekanye, J. (1988). Nigerian armed forces to take over conduct of future elections: a recommendation. Quarterly Journal of Administration, 23(1-2), 27-38. 


\section{Khazanah Sosial, Vol. 3 No. 2 : 54 - 65}

Gagging Electoral Fraud in Nigeria: The Imperative of Electoral Reforms Christiantus Ifeanyi Adebowale Oke and Harriet Omokiniovo Efanodor-Obeten

Akasike, C. (2016). Apologise for Okrika Attack, APC Tells Jonathan Wife. Www.Punchng.Com. www.punchng.com

Aluaigba, M. T. (2016). Democracy Deferred: the effects of electoral malpractice on Nigeria's Path to Democratic consolidation. Journal of African Elections, 15(2), 136-158.

Ashindorbe, K. (2018). Electoral violence and the challenge of democratic consolidation in Nigeria. India Quarterly, 74(1), 92-105.

Avgerou, C., Masiero, S., \& Poulymenakou, A. (2019). Trusting e-voting amid experiences of electoral malpractice: The case of Indian elections. Journal of Information Technology, 34(3), 263289.

Belloumar, M., \& Lamidi, K. O. (2018). A Review Of The 2015 and 1999-2011 General Elections in Nigeria Using Pippa Norris'electoral Integrity Framework (Eif). Annals of the „Ovidius” University of Constanţa-Political Science Series, 7, 75-104.

Bentley, A. F. (2013). The process of government. Harvard University Press.

Birch, S. (2011). Electoral malpractice. Oxford University Press on Demand.

Confidence Chia, N., \& David Nchinda, K. (2018). Cameroon Political Leadership and Nightmare Episode 1982-2008: The Opportunities Lost and Gained In Securing A National Consensus. Journal of Advances in Social Science and Humanities, 4(8), 209-226.

Ebong, I. B., \& Ozinegbe, O. (2020). The Politics Of Military Withdrawal in Governance: The Nigerian Experience. POLITICS, 3(04).

Ekiugbo, A., \& Umukoro, N. (2011). Democracy and Electoral Fraud in African Government and Politics. Mindex Publishing Company Limited.

Fatai, A. (2018). The Significance of Elections in Africa: 2015 elections and democratic consolidation in Nigeria. African Journal of Political Science and International Relations, 12(10), 208-219.

Gberevbie, D. E. (2014). Democracy, democratic institutions and good governance in Nigeria. Eastern Africa Social Science Research Review, 30(1), 133-152.

Isah, M. (2020). Electoral reform as huge step to citizens' political participation available at. Www.Vanguardngr.Com. https://www.vanguardngr.com/2020/07/electoral-reform-ashuge-step-to-citizens-political-participation

Joseph, E. (2020). The Impacts of Political Corruption on Democratic Consolidation and the Electoral Process in Nigeria. Academicus International Scientific Journal, 11(21), 38-45.

Kew, D. (2010). Nigerian elections and the neopatrimonial paradox: in search of the social contract. Journal of Contemporary African Studies, 28(4), 499-521.

Mauk, M. (2020). Electoral integrity matters: how electoral process conditions the relationship between political losing and political trust. Quality \& Quantity, 1-20.

Mawere, M., \& Mwanaka, T. R. (2015). Democracy, Good Governance and Development in Africa. Langaa RPCIG.

Ndubuisi, U., \& Ebubechukwu, C. V. (2021). Election Petition Tribunal and Democratisation: An Assessment of the Judiciary in Nigeria. FUDMAJOURNAL OF POLITICS AND INTERNATIONAL AFFAIRS, 3(7), 12-23.

Nwachukwu, L. C. (2018). Electoral Violence and Democratic Consolidation in Nigeria: Reflections On The 2015 General Elections. Online Journal of Arts, Management \& Social Sciences, 3(2).

Ojo, 0. (2019). tive of electoral reforms as 736 petitioners go to tribunals. The Guardian Newspapers.

Ojukwu, U. G., Mazi Mbah, C. C., \& Maduekwe, V. C. (2019). Elections and democratic consolidation: A study of 2019 general elections in Nigeria. Direct Research Journal of Social Science and Educational Studies, 6(4), 53-64.

Oloruntoba, S. O., Ishola, E. B., \& Ekanade, I. K. (2020). Globalization, Poverty, and Development in Africa: Looking Past to the Future. In Challenges of Globalization and Prospects for an Intercivilizational World Order (pp. 725-748). Springer.

Omotola, J. S. (2011). Electoral reform and the prospects of democratic consolidation in Nigeria: democratisation in Nigeria. Journal of African Elections, 10(1), 187-207. 


\section{Khazanah Sosial, Vol. 3 No. 2 : 54 - 65}

Gagging Electoral Fraud in Nigeria: The Imperative of Electoral Reforms Christiantus Ifeanyi Adebowale Oke and Harriet Omokiniovo Efanodor-Obeten

Oni, M. A. (2004). Electoral Fraud and Legitimacy Crisis in Post Independence Nigeria. International Review of Politics and Development, 2(2).

Onuba, F. (2015). PDP, APC spend N4.9bn on publicity, others - Group. www.punchng.com

Osha, S. (2020). Ken Saro-Wiwa's Shadow (Expanded Edition): Politics, Nationalism and the Ogoni Protest Movement. Cambridge Scholars Publishing.

Schreier, M., Janssen, M., Stamann, C., Whittal, A., \& Dahl, T. (2020). Qualitative Content Analysis: Disciplinary Perspectives and Relationships between Methods-Introduction to the FQS Special Issue" Qualitative Content Analysis II". Forum Qualitative Sozialforschung/Forum: Qualitative Social Research, 21(1).

Truman, D. B. (1951). The governmental process: Political interests and public opinion.

Ujo, A. A. (2012). Understanding the 2011 general elections in Nigeria: the beginning of a new era. International Institute for the Study of Election and Election Managem ent (IISEEM).

Urquhart, C. (2012). Grounded theory for qualitative research: A practical guide. Sage. 